AMERICAN SOCIETY OF PEDIATRIC NEPHROLOGY

Murray Hill Suite- New York Hilton

April 25, 1978 - 9 a.m.-5 p.m.

RECENT ADVANCES IN IMMUNE MEDIATED KIDNEY DISEASE

1. Introductory Remarks

Robert L. Vernier, M.D.

2. Immunogenetics and Renal Disease

Alfred F. Michael, M.D.

3. Mediators of Renal Injury
A) Clark D. West, M.D.
B) Chester A. Alper, M.D.
C) Ronald Glasser, M.D.

4. The Glomerular Filter - New Concepts

Alan Robson, M.D.

LUNCH

5. Immune Complex Diseases and Mechanisms

A) New Experimental Models and Concepts John R. Hoyer, M.D.

B) Antigens Implicated in Human Renal Disease Rawle Mclntosh, M.D.

6. The Glomerular Mesangium: Kinetic Studies and Implications

S. Michael Mauer, M.D.

5:00 p.m. - Business Meeting

6-8 p.m. - Reception 


\title{
THE AMERICAN PEDIATRIC SOCIETY and
}

THE SOCIETY FOR PEDIATRIC RESEARCH

\author{
Combined \\ Program and Abstracts
}

The New York Hilton at Rockefeller Center

New York

April 26-28, 1978 
The Blood Club will be held at the New York Hilton in the Sutton Room, North and Center, on Wednesday, April 26, 1978, from 7:30 to $9: 30$ p.m.

1) Vitamin E in Pediatric Diseases. M. Stuart, M.D., and F. Oski, M.D.: Platelet Defect in Vitamin E Deficiency

2) J. White, M.D.: NBT and Vit. E, Platelet. Iron, and Prostaglandin Process

3) S. Gross, M.D.: Neonatal Anemia. Vit. E., Selenium and GSH PX

4) R. Baehner, M.D.: Neutrophiles and Vit. E. (Constipated neutrophil) 
THE AMERICAN PEDIATRIC SOCIETY

88th Annual Meeting

OFFICERS

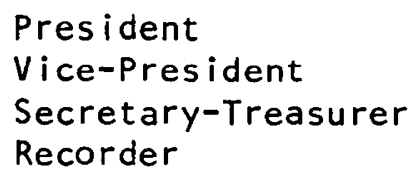

IN MEMORIAM

William S. Langford Heyworth N. Sanford Marcel Lelong A. Ashley Weech

COUNCIL
Philip R. Dodge Joseph Dancis

Paul G. Quie
C. Henry Kempe Norman Kretchmer David Goldring Floyd W. Denny, Jr.

Moses Grossman, Chairman

Eleanor Colle Thomas K. 0 liver, Jr. Elia M. Ayoub

\section{THE SOCIETY FOR PEDIATRIC RESEARCH \\ 48th Annual Meeting}

Arthur E. McElfresh

Harold Stuart

Robert A. Lyon

OFFICERS

President
Vice-President
President-Elect
Secretary-Treasurer

COUNCIL

Anne A. Gershon

Michael A. Heymann

Rawle M. Mclntosh
Frank A. Oski

Lowell A. Glasgow

Jo Anne Brasel

John D. Johnson

Joseph B. Warshaw, Membership Secretary 